\title{
VARIATION IN ANTIOXIDANT ATTRIBUTES AND INDIVIDUAL PHENOLICS OF CITRUS FRUIT PEELS IN RELATION TO DIFFERENT SPECIES AND EXTRACTION SOLVENTS
}

\author{
SADAF ZAHOOR ${ }^{1}$, FAROOQ ANWAR ${ }^{1,2 *}$, TAHIR MEHMOOD ${ }^{\prime *}$, BUSHRA SULTANA $^{3}$ AND RAHMAN QADIR ${ }^{1}$ \\ ${ }^{1}$ Department of Chemistry, University of Sargodha, Sargodha, Pakistan. \\ ${ }^{2}$ Department of Pharmaceutical Chemistry, College of Pharmacy, Prince Sattam bin Abdulaziz University, P.O. Box 173 Al-Kharj-11942, Saudi Arabia.
}

${ }^{3}$ Department of Chemistry, University of Agriculture Faisalabad, Pakistan.

\begin{abstract}
Major objective of this study was to appraise the variation of antioxidant activity, total phenols, total flavonoids and individual phenolic acids among fruit peels from five species of Citrus namely C. sinensis 'Valancia' (Mausami), C. sinensis 'Maltaise Sanguine' (Red blood), C. reticulata (Kinnow), C. reticulata Blanco 'Merisol' (Fruiter), and C. paradisi 'Macfadyen' (Grapefruit) as function of extraction solvents. The extract yield from the fruit peels of the selected Citrus species by using four solvents varied significantly $(p<0.05) 17.56-49.13 \mathrm{~g} / 100 \mathrm{~g}$ in relation to the extraction media and type of peel. The highest extraction yield was obtained with $100 \%$ methanol from Red blood (C. sinensis 'Maltaise Sanguine') peel while the least with 100\% ethanol from Fruiter (C. reticulata Blanco 'Merisol') peel. The total phenolic contents (TPC), total flavonoid contents (TFC), DPPH radical scavenging activity ( $\left.\mathrm{IC}_{50}\right)$ and reducing power [FRAP (EC F $_{50}$ ) for peel extracts ranged from 13.69 to $66.10 \mathrm{GAE} \mathrm{mg} / \mathrm{g}$ of dry weight (DW), 9.34 to $28.99 \mathrm{CE} \mathrm{mg} / \mathrm{g} \mathrm{DW}, 0.33$ to $2.32 \mathrm{mg} / \mathrm{mL}$ and 2.05 to $6.76 \mathrm{mg} / \mathrm{mL}$, respectively. According to HPLC analysis of peel extracts, gallic acid and protocatechuic acid with contribution $11.96-96.08$ and $109.18-578.59 \mathrm{mg} / \mathrm{kg}$ of extract, respectively, were detected to be the main phenolic acids among others. Total amount of individual phenolic acids (TPAs) in the tested peels varied over 18.37 to 1015.99 $\mathrm{mg} / \mathrm{kg}$ of extract. The highest amount of TPAs was extracted in Red blood (C. sinensis 'Maltaise Sanguine') with $80 \%$ methanol while the least in Grapefruit ( $C$. paradisi 'Macfadyen') with $100 \%$ methanol. It can be concluded from the present data that both the species and extraction solvents have notable effect on the antioxidant attributes and phenolics of citrus peels. Overall, the results of this study showed that extracts from peel of Red blood (C. sinensis 'Maltaise Sanguine'), among others, possessed superior antioxidant activity and greater amount of phenolic acids.
\end{abstract}

Key words: Citrus Peel extracts, Extraction solvents, Antioxidant activity, Total phenolics and Flavonoids, Phenolic acids, HPLC

\section{INTRODUCTION}

Oxidative reactions not only decrease the nutritive value of food products ${ }^{1}$ nevertheless, the reactive oxygen species (ROS), formed as a result of oxidation, are also harmful for the health of consumers ${ }^{2}$. Antioxidant act as scavengers and inhibitors of free radicals and thus can protect the food and human body against oxidation mediated damages ${ }^{3}$. Several food and pharmaceutical industries use synthetic antioxidants to protect their products from oxidative deterioration thus prolonging their shelf-life $e^{4-6}$. Synthetic antioxidants, although well recognized due to their greater efficacy, can cause health problems such as liver damage and certain cancer ${ }^{7}$. On the other hand, natural antioxidants from plants possess several potential medicinal benefits ${ }^{8}$. Epidemiological studies reveal that consumption of fruits and vegetables, due to their rich profile of antioxidant nutrients, is positively linked with the decreased incidence of cancer, ageing, inflammation and cardiovascular disorders ${ }^{9,10}$.

Citrus fruits including oranges, mandarins, limes, lemons, sour oranges, and Grapefruits are popular throughout the world due to their refreshing juices, nutritive value and health benefits ${ }^{11-13}$. Citrus [Rutaceae family] containing 17 species and 52 varieties ${ }^{14}$ are the world's largest fruits commodity ${ }^{15}$ with estimated annual production of 80 million tons ${ }^{16}$. Among which 49.6 million tons are for Citrus sinensis (oranges), 24.0 million tons Citrus reticulata (mandarins/tangerine) and 5.3 million tons Citrus paradisi (Grapefruits) ${ }^{17}$. According to reports Citrus fruits have shown anti-inflammatory activity and protection against coronary heart diseases and cancer ${ }^{18}$. Several studies reveal that Citrus fruits and juices exhibit potent antioxidant activity which can be linked to the presence of a wide array of bioactive phytochemicals such as hydroxybenzoic and hydroxycinnamic acids, acetophenones, terpenoids, flavonoids, tannins, limonoids ${ }^{12}$ and flavonoids ${ }^{13}$.

Currently, world over interest is developed to extract valuable compounds from under-utilized agro-wastes so as to explore their commercial uses in cosmetics, medicines and food preservation ${ }^{19}$. One of the under-utilized fruit processing waste, namely Citrus peels, are a potential source of several bioactives such as phenolics, flavonoids, tannins, and specifically limonoids which are rare to other plants $\mathrm{s}^{12,20}$. These bioactives have important biological activities including antioxidant, antimicrobial, anti-inflammatory and anticancer ${ }^{20}$.

Extraction is the first important step in the recovery and purification of active ingredients from plant materials ${ }^{21}$. Solvent extraction method is a traditional method for extraction and is more frequently used for the isolation of bioactive compounds. In this method, extraction yield of bioactive compounds is dependent on conditions of extraction and the solvent polarity. Since there was no study reporting any kind of damaging effect to plant bioactive compounds in the solvent extraction method, hence it is being used extensively for extraction. ${ }^{22}$

Pakistan being one of the top ten Citrus producing countries of the world ${ }^{23}$ produces a large quantity of Citrus peels as agro-waste due to Citrus fruit processing and consumption. However, very little is known about phenolics composition and antioxidant activity of Citrus fruit peels from different local Citrus varieties. So, it would be worthwhile to evaluate the antioxidant principles of peels of locally available Citrus species leading to exploring their potential prospects in pharmaceuticals and food industries as natural preservatives and antioxidants. With this in mind, total phenols, total flavonoids and antioxidant properties along with individual phenolic acids composition of the fruit peels from five important and widely cultivated Citrus species were studied in the present work.

\section{EXPERIMENTAL}

\section{Materials}

The fruit samples of authenticated Citrus species including Fruiter (Citrus reticulate blanco 'Merisol'), Grapefruit (Citrus paradisi 'Macfadyen'), Kinnow (Citrus reticulata), Mausami (Citrus sinensis 'Valencia') and Red blood (Citrus sinensis 'Maltaise Sanguine') were obtained from the local fruit market and fruit farms of Sargodha, Pakistan. All the samples were peeled off manually in order to separate the peels which were cut into small pieces and ambient-dried in a well-ventilated working laboratory. The dried peel material was ground into a fine powder with a grinder. The ground material that passed through 80-mesh sieve was used for the extraction of antioxidant components. All other chemicals (analytical grade) used in different experiments were purchased from Sigma-Aldrich Chemical Corporation, Germany.

Preparation of Extracts: Extraction of antioxidant components was performed on a conventional orbital shaker, with different solvents such as $100 \%$ methanol, $100 \%$ ethanol, $80 \%$ methanol (80: 20 methanol:water $\mathrm{v} / \mathrm{v}$ ) and $80 \%$ ethanol (80: 20 ethanol:water $v / v)$ for 8 hours at $30{ }^{\circ} \mathrm{C}$. The ratio of sample and solvent in either case was kept to be 1:10 (w/v). After filtration the residue was extracted again using the procedure described above and the two extractions pooled. The filtrate was freed of excess solvent under reduced pressure using a vacuum rotary evaporator (Evaporatore rotante Heidolph LaboRota 4000 /HB Efficient). The percent extract yields were calculated based upon solvent-free extract mass and the semi-solid crude extracts preserved at 4 ${ }^{\circ} \mathrm{C}$ in a refrigerator after quantitatively transferring into a small volume of the respective extraction solvent ${ }^{5,24}$. 
Determination of Antioxidant Activity: Following in-vitro assays were performed to assess the antioxidant activity of the citrus fruit peel extracts (CFPE) prepared.

Determination of Total Phenols: Total phenols content (TPC) of the CFPE was estimated according to Folin-Ciocalteu assay as described by Kalpna et al. (2011) $)^{25}$. In this assay, $0.5 \mathrm{~mL}$ of CFPE extract $(2 \mathrm{mg} / \mathrm{mL})$ was taken in a test tube and mixed with $0.1 \mathrm{~mL}$ of Folin-Ciocalteu reagent $(0.5$ $N$ ). The mixture was incubated at room temperature for $15 \mathrm{~min}$ and after that $2.5 \mathrm{~mL}$ of $7 \%(\mathrm{~W} / \mathrm{V})$ sodium carbonate solution was added and the mixture again incubated for $30 \mathrm{~min}$ at laboratory conditions. The absorbance of the final reaction mixture was recorded at $700 \mathrm{~nm}$ using a spectrophotometer (CECIL CE 7200). The amount of TP was calculated using Gallic acid standard calibration curve constructed by preparing standard solutions within the range of 10-200ppm $\left(\mathrm{R}^{2}=0.99830\right)$. The data were expressed as Gallic acid equivalents (GAE) $\mathrm{mg} / \mathrm{g}$ of dry weight of extract. All the measurements were made in triplicate and the results computed as average.

Determination of Total Flavonoids: The total flavonoids content (TFC) in CFPE was estimated by the method reported by Kalpna et al. (2011) ${ }^{25}$. In this test, one $\mathrm{mL}$ of aqueous extracts $(10 \mathrm{mg} / \mathrm{mL})$ was separately placed in a test tube and distilled water added to make the total volume up to $5 \mathrm{~mL}$. Then 0.3 $\mathrm{mL} \mathrm{NaNO}(1: 20)(5 \% \mathrm{w} / \mathrm{v})$ was added into the test tube. The reaction mixture was placed at room temperature for $5 \mathrm{~min}$ and then $0.3 \mathrm{~mL} \mathrm{AlCl}(1: 10)(10 \%$ $\mathrm{W} / \mathrm{V}$ ) was further added. The mixture was kept again at room temperature for 6 min followed by addition of $2 \mathrm{~mL}$ of $\mathrm{NaOH}(1 M)$. An appropriate volume of distilled water was added to make the total volume up to $10 \mathrm{~mL}$. The final solution obtained was mixed well on a vortex machine and then the absorbance recorded against a blank at $510 \mathrm{~nm}$ with a spectrophotometer. The results were calculated using standard calibration curve $\left(10-500 \mathrm{ppm}, \mathrm{R}^{2}=0.9911\right)$ and were expressed as catechin equivalent $(\mathrm{CE} \mathrm{mg} / \mathrm{g})$ dry weight basis. All the samples were analyzed in triplicate and the results averaged.

DPPH Scavenging Activity Assay: The antioxidant activity of CFPE towards scavenging 1, 1 diphenyl-2-picrylhydrazyl radical (DPPH) was assessed calorimetrically according to the method described by Zhishen et al. $(1999)^{26}$. In this assay, $1 \mathrm{~mL}$ of extracts (concentration range $0.25-2.0 \mathrm{mg} / \mathrm{mL}$ ) was taken in a test tube and mixed with $2 \mathrm{~mL}$ of $0.1 \mathrm{mM}$ DPPH methanolic solution (freshly prepared) followed by further addition of methanol to make the final volume upto $4 \mathrm{~mL}$. The reaction mixture was incubated at room temperature for $30 \mathrm{~min}$ in darkness. The absorbance was then taken at $517 \mathrm{~nm}$ with a spectrophotometer. A synthetic antioxidant, BHA (butylated hydroxyl anisole) was used as a positive control. $\mathrm{IC}_{50}$, the concentration of extract which scavenged/neutralized $50 \%$ of DPPH free radicals, was calculated using the formula:

$\%$ scavenging activity $=\left(\mathrm{A}_{\text {control }-} \mathrm{A}_{\text {extract }}\right) / \mathrm{A}_{\text {control }} \times 100$

$\mathrm{A}_{\text {control }}=$ the absorbance of control which contain all reagents except sample $\mathrm{A}_{\text {extract }}=$ the absorbance of extract

Determination of Reducing Power: The reducing power of CFPE was determined as reported earlier by Zhuang et al. $(2012)^{27}$, with slight modifications. According to this assay, different concentrations of extracts (2$10 \mathrm{mg} / \mathrm{mL})$ were mixed with $3.5 \mathrm{~mL}$ phosphate buffer $(0.2 \mathrm{M}, \mathrm{pH} 6.6)$ and 2 $\mathrm{mL}$ of $1 \%$ potassium ferricyanide. The mixture was incubated for $20 \mathrm{~min}$ at room temperature. After that $2.5 \mathrm{~mL}$ of $10 \%$ trichloroacetic acid was added to the mixture and the mixture centrifuged ( 800 Electric Laboratory Centrifuge JIN YI, China) at $3000 \mathrm{rpm}$ for $10 \mathrm{~min}$. By using a pasture pipette, $2.5 \mathrm{~mL}$ of supernatant was collected and mixed with $2.5 \mathrm{~mL}$ of distilled water. To this mixture $0.5 \mathrm{~mL}$ of $0.1 \%$ ferric chloride was added and then absorbance of the final reaction mixture taken at $700 \mathrm{~nm}$ with a spectrophotometer. The increase in absorbance of the mixture directly correlated to reducing power of the extract.

HPLC Analysis of Phenolic Acids: The individual phenolic acids composition was analyzed by using Reverse Phase High Performance Liquid Chromatography (RP-HPLC). Separation of phenolic acids was carried out on Varian HPLC using ODS $(\mathrm{C} 18)$ reversed phase column $(250 \times 4.6 \mathrm{~mm})$. The mobile phase used was acidified acetonitrile $(99.5 \%)$ at a constant flow rate of $1 \mathrm{~mL} / \mathrm{min}$ in isocratic mode. $50 \mathrm{mg}$ of sample extract was dissolved in mobile phase and filtered by micro syringe filter before injection. A $20 \mu \mathrm{L}$ sample was injected into the column using a micro syringe. The detection was carried out at $280 \mathrm{~nm}$. The targeted phenolic acids were identified by matching their relative retention times with those of pure standards. The contents of individual compounds were calculated on the basis of peak area measurement ${ }^{28}$.

Statistical Analysis: The data was expressed as mean values \pm SD for triplicate measurements. Analysis of variance was performed using 2-way ANOVA. Significant difference of means among citrus peels and extraction solvents were considered at $P<0.05$. Statistical analysis was done by using
SPPS version 22.0.0.0 software ${ }^{29}$

\section{RESULTS AND DISCUSSION}

\section{Yield of Extracts}

The extraction yield of antioxidant components from a plant material depends on the nature and concentration of solvent so it is important to select an appropriate solvent for recovery of maximum amount of extractable compounds. Due to polar characteristics of most of the natural phenolic antioxidants, usually some polar solvents such as methanol and ethanol in pure state or as aqueous mixture are used for the extraction of such components from plant matrices ${ }^{10}$.

The extraction yield for antioxidant components from different Citrus species peels with pure and aqueous methanol (100 and $80 \%)$ and pure and aqueous ethanol $(100$ and $80 \%)$ is shown in Table 1. The extract yield from peels of different Citrus species differed over a wide range, 17.56 to $49.50 \%$ $(\mathrm{g} / 100 \mathrm{~g})$. The maximum yield $(46.50 \%)$ was recorded with $100 \%$ methanol for Red blood (C. sinensis 'Maltaise Sanguine'), while the minimum (17.56 $\%$ ) by $100 \%$ ethanol for Fruiter (C. reticulata Blanco 'Merisol'). The range of \% extract yields for different Citrus species peels on individual basis with different solvents was found to be $17.5-44 \%$ for Fruiter (C. reticulata Blanco 'Merisol'), 28.79-43.39 \% for Grapefruit (C. paradisi 'Macfadyen'), 43.31$49.13 \%$ for Kinnow (C. reticulate), 31.65-45.04 \% for Mausami (C. sinensis 'Valancia') and 32.68-46.50\% for Red blood (C. sinensis 'Maltaise Sanguine'). Based on the results, the extraction efficacy of different solvents (used in the present study) was found to be $80 \%$ methanol $>80 \%$ ethanol $>100 \%$ methanol $>100 \%$ ethanol, while the order of \% yield with respect to species was Kinnow $(C$. reticulata $)>\operatorname{Red}$ blood $(C$. sinensis 'Maltaise Sanguine) $>$ Mausami $(C$. sinensis 'Valancia') $>$ Grapefruit $(C$. paradisi 'Macfadyen') $>$ Fruiter (C. reticulata Blanco 'Merisol'). Relatively a higher yield of extract with $80 \%$ ethanol and $80 \%$ methanol revealed that aqueous solvents have greater efficacy towards recovering antioxidant components from Citrus peels. The results showed that the effect of different solvents and sample type on percentage extraction yield is significant $(P<0.05)$.

The present results showing a higher extract yield with aqueous alcoholic mixtures are in agreement with those investigated by kim $(2013)^{30}$ showing greater extracts yield with aqueous ethanol from dried Citrus (Citrus unshiu) fruit peel from Chejudo, South Korea. An earlier study ${ }^{15}$, reported a lower extraction yield by ethanol (about $18 \%$ ) for peels of Citrus sinensis and Citrus limon from fruits analyzed from India than that observed in the present work. In another related study, Shie and Lay $(2013)^{31}$ reported a higher extraction yield by methanol (66.47-23.67\%) from Citrus limon fruits collected from Jilouru Township, Pingtung Country, Taiwan. Kalpna et al. $(2011)^{25}$ also reported higher extract yield by methanol as compare to other solvents (hexane, acetone) from peels of Moringa oleifera (21.05), Lagenaria siceraria (19.69), Ananas comosus (17.30), Mangifera indica (15.82), Momordica charantia (11.25), Solanum tuberosum (10.17) and Luffa acutangula (7.24). Such differences may be attributed to different factors such as varietal variations, nature of the extractable bioactive compounds of the peels as well as the efficacy of extraction procedure and solvent employed ${ }^{32}$. The present study revealed ethanol to be more effective solvent for extraction of antioxidant components from Citrus peel. According to research reports ethanol is preferred for extraction of antioxidant compounds ${ }^{33}$ because of its lower toxicity, biodegradable and bio-solvent features. Currently, there is much focus on green extractions of bioactives involving the use of eco-friendly bio-solvents, especially when the compounds are extracted for functional food or nutraceutical applications ${ }^{34}$

Values are means $\pm \mathrm{SD}(\mathrm{n}=3)$ of three separate experiments. Different caps letter in subscript within the same column show significant $(p<0.05)$ differences of means among Citrus species. Different superscript letters within the same row show significant $(p<0.05)$ differences of means among extraction solvents.

\section{Total Phenolic Contents (TPC)}

Citrus fruits have several health promoting components including vitamin $\mathrm{C}$, carotenoids and phenolic compounds $\mathrm{s}^{35}$. Phenolic compounds are considered as a major group of phytochemicals contributing to antioxidant potential of plant materials due to their prominent free radical scavenging activity ${ }^{24}$. In the present study, TPC were determined by means of Folin-Ciocalteu reagent (FCR) assay. Although, the chemical features and exact functionality of FolinCioclateu reagent is unclear, but this assay is widely used for the estimation of total phenols and thus antioxidant activity of plant materials due to its easiness and reproducibility. A very good correlation has been found between TPC and antioxidant activity ${ }^{24}$. 
Table 1: Extract yields (g/100g) from peels of five Citrus species using different solvents.

\begin{tabular}{|c|c|c|c|c|}
\hline \multirow{2}{*}{ Samples } & \multicolumn{4}{|c|}{ Percentage yield $(\mathrm{g} / 100 \mathrm{~g})$} \\
\hline & methanol & $80 \%$ methanol & $100 \%$ ethanol & $80 \%$ ethanol \\
\hline Mausami (C. sinensis 'Valancia') & $40.86 \pm 1.35_{\mathrm{A}}^{\mathrm{a}}$ & $45.04 \pm 1,76^{\mathrm{a}}{ }_{\mathrm{A}}$ & $31.66 \pm 0.63^{\mathrm{b}}{ }_{\mathrm{A}}$ & $39.32 \pm 0.11_{\mathrm{A}}^{\mathrm{a}}$ \\
\hline Fruiter (C. reticulata Blanco 'Merisol') & $44.24 \pm 0.45^{\mathrm{a}}{ }_{\text {в }}$ & $38.16 \pm 1.77^{\mathrm{a}}{ }_{\mathrm{B}}$ & $17.56 \pm 1.27^{\mathrm{b}}{ }_{\mathrm{B}}$ & $40.21 \pm 0.32^{\mathrm{a}}$ \\
\hline Red blood (C. sinensis 'Maltaise Sanguine) & $46.50 \pm 1.26^{\mathrm{a}}{ }_{\mathrm{C}}$ & $44.89 \pm 0.18^{\mathrm{a}}{ }_{\mathrm{C}}$ & $32.68 \pm 0.40^{\mathrm{b}}{ }_{\mathrm{C}}$ & $44.46 \pm 0.71^{\mathrm{a}}$ \\
\hline Kinnow (C. reticulata) & $43.77 \pm 1.72^{\mathrm{a}}{ }_{\mathrm{D}}$ & $46.19 \pm 0.61^{\mathrm{a}}{ }_{\mathrm{D}}$ & $43.31 \pm 0.29^{\mathrm{b}}$ & $49.13 \pm 0.12^{\mathrm{a}}$ \\
\hline Grapefruit (C. paradisi 'Macfadyen') & $36.34 \pm 3.03^{\mathrm{a}}{ }_{\mathrm{A}}$ & $43.39 \pm 1.30_{\mathrm{A}}^{\mathrm{a}}$ & $28.79 \pm 1.33_{\mathrm{A}}^{\mathrm{b}}$ & $42.52 \pm 1.47^{\mathrm{a}}$ \\
\hline
\end{tabular}

Values are means $\pm \mathrm{SD}(\mathrm{n}=3)$ of three separate experiments. Different caps letter in subscript within the same column show significant $(p<0.05)$ differences of means among Citrus species. Different superscript letters within the same row show significant $(p<0.05)$ differences of means among extraction solvent.

Total phenolic contents for peels of five Citrus species extracted by different solvents (100\% methanol, $80 \%$ methanol, $100 \%$ ethanol, $80 \%$ ethanol) ranged from 13.69 to $66.10 \mathrm{mg}$ GAE/g DW (Table 2). Within the species the lowest TPC was noted for Red blood $13.69 \mathrm{mgGAE} / \mathrm{g}$ ) while the highest for Kinnow (C. reticulata) $(66.10 \mathrm{mg} \mathrm{GAE} / \mathrm{g})$. TPC of peels of different species were found to be 15.66-55.97 for Fruiter (C. reticulata Blanco 'Merisol'), 22.8258.03 for Grapefruit (C. paradisi 'Macfadyen'), 28.204-65.81 for Kinnow (C. reticulata), 21.11-60.52 for Mausami (C. sinensis 'Valancia') and 13.69-62.38 for Red blood (C. sinensis 'Maltaise Sanguine) (Table 2).

The efficacy of different solvents towards extraction of TPC from peels was noted to be $100 \%$ methanol $>80 \%$ methanol $>100 \%$ ethanol $>80 \%$ ethanol while within the species Kinnow (C. reticulata) peel has highest amount of phenolics followed by Grapefruit (C. paradisi 'Macfadyen'), Mausami (C. sinensis 'Valancia'), Red blood (C. sinensis 'Maltaise Sanguine) and Fruiter (C. reticulata Blanco 'Merisol'). The present results showed that both the extraction solvent and species have significant $(p<0.05)$ effect on the estimated contents of total phenolics (Table 2)

The results of the present study are in agreement to those reported by $\mathrm{Li}$ et al. $(2006)^{36}$ who investigated that peels from Grapefruit have higher total phenolic contents followed by mandarine, yeb Ben lemon, orange and mayer lemon peel. However, TPC of peels in this analysis are considerably higher than those investigated by Mathur et al. $(2011)^{37}, 148 \mu \mathrm{g} / \mathrm{g}$ for Kinnow $(C$. reticulata), $134 \mu \mathrm{g} / \mathrm{g}$ for orange and $28 \mu \mathrm{g} / \mathrm{g}$ for shaddock from India. The present TPC are also higher than that reported by Zvaigzne et al., $(2009)^{38}$ for different Citrus fruit juices from Brazil and Israel indicating that peels have greater amounts of TP than juices. The peel, being the outer covering of many fruits, is a valuable source of phenolics and other high-value bioactives and hence often contains greater amounts of phenolics and antioxidants relative to pulp part ${ }^{39}$.

As far as efficacy of different solvents towards extraction of phenolics form peels is concerned, the present trend is different than that investigated by Hegazy and Ibrahium (2012) ${ }^{35}$ who determined a higher value of phenolics (mg/g of extract) in ethanol (169.38) extract rather than methanol (165.38) extract of orange peel. There are several factors such as polarity of solvent, genetic makeup of citrus species and chemical nature of the extractable compounds which may affect the extraction yield of phenolics.

\section{Total Flavonoid Contents (TFC)}

Total flavonoid contents (TFC) in peels of different Citrus species as extracted by different solvents ranged from 6.93-29.43 mg CE/g of DW (Table 2). The maximum amount of flavonoids was extracted with $100 \%$ ethanol from Kinnow (C. reticulata) peel $(29.43 \mathrm{mg} \mathrm{CE} / \mathrm{g})$ while the minimum by $100 \%$ ethanol from Mausami (C. sinensis 'Valancia') peel (6.93 mg CE/g). On individual basis, the estimated TFC (mg CE/g of DW) for different Citrus species peels varied from 10.20-23.62 for Fruiter (C. reticulata Blanco 'Merisol'), 17.66 -28.76 for Grapefruit (C. paradisi 'Macfadyen'), 14.28-29.43 for Kinnow (C. reticulata), 6.93-14.27 for Mausami (C. sinensis 'Valancia') and 17.66-28.9 for Red blood (C. sinensis 'Maltaise Sanguine). With regard to extraction efficacy of solvents, a random but significant $(p<0.05)$ effects were noted while within the citrus species the amount of flavonoids in Grapefruit (C. paradisi 'Macfadyen') was higher than Red blood followed by Kinnow (C. reticulata), Fruiter (C. reticulata Blanco 'Merisol') and then Mausami (C. sinensis 'Valancia'). Citrus are one of the good sources of flavonoids which contribute to anti-allergy, anti-inflammatory and antioxidant properties of these fruits. Interestingly, hesperidin, a main constituent of Citrus flavonoids, is beneficial in heart and brain blood vessels diseases and bronchitis treatment ${ }^{9}$.

TFC of citrus peels in the present analysis are comparable with the values reported by Hegazy and Ibrahium (2012) ${ }^{35}$ for Egyptian orange peel extract using methanol $(28.36 \mu \mathrm{g} / \mathrm{g})$ and ethanol $(29.75 \mu \mathrm{g} / \mathrm{g})$. The present values for methanolic extract are also comparable with the results of Ghasemi et al. $(2009)^{18}$ for different Citrus species peels (5.2-23.2 QE mg/g of DW). On the other hand, the present TFC values are quite higher than that investigated by Chen et al. (2010) $)^{9}$ for ethanolic extracts of peels of Citrus reticulate Blanco (4.67-5.81 mg RE/g DW). Such variations in TFC can be understood based upon the nature and origin of species and extraction solvent.

\section{DPPH radical scavenging activity}

DPPH radical scavenging assay is commonly used for the assessment of free radical scavenging activity of antioxidants. DPPH is a stable organic free radical and possess the ability of accepting an electron or hydrogen radical. It is basically a violet color radical which upon receiving proton from any hydrogen donor species ${ }^{40}$ such as phenolics, loses its chromophor and becomes yellow. The degree of discoloration indicates the free radical scavenging potential and subsequent antioxidant activity of the extracted compounds. It is widely accepted that as the concentration of phenolic compounds or degree of hydroxylation of phenolic compound increases ${ }^{41}$, DPPH radical scavenging activity and hence antioxidant activity of plant extract or related compound also increases. Concentration of sample at which the inhibition percentage reaches $50 \%$ is its $\mathrm{IC}_{50}$ value. $\mathrm{IC}_{50}$ is negatively related to the antioxidant activity as it express the amount needed to decrease radical concentration by $50 \%$. A lower $\mathrm{IC}_{50}$ value indicates a higher antioxidant activity ${ }^{41}$

DPPH scavenging activity (in terms of $\mathrm{IC}_{50 \text { values }}$ ) for different solvent extracts from peels of different Citrus species ranged from $0.33-2.32 \mathrm{mg} / \mathrm{mL}$ (Table 3). The highest value was noted for $100 \%$ ethanolic extract of Fruiter (C. reticulata Blanco 'Merisol') $(2.32 \mathrm{mg} / \mathrm{mL})$ while the lowest for $80 \%$ methanolic extract of Kinnow $(C$. reticulata $)(0.33 \mathrm{mg} / \mathrm{mL}) . \mathrm{IC}_{50}(\mathrm{mg} / \mathrm{mL})$ values for different species peels were as: $0.66-2.32$ for Fruiter $(C$. reticulata Blanco 'Merisol'), 0.50-0.63 for Grapefruit (C. paradisi 'Macfadyen'), 0.331.18 for Kinnow (C. reticulata), 0.45-0.76 for Mausami (C. sinensis 'Valancia') and $0.37-0.67$ for Red blood (C. sinensis 'Maltaise Sanguine). The ability of Citrus peel extracts to scavenge free radicals varied significantly $(p<0.05)$ in relation to extraction solvents and within the species. Aqueous methanol ( $80 \%$ methanol) extract exhibited the highest radical scavenging among others. The free radical scavenging order for different solvents extracts was followed as: $10 \%$ ethanol extract $>80 \%$ methanol extract $>100 \%$ methanol extract $=80 \%$ ethanol extract. On species basis the free radicals scavenging order was followed to be: Red blood (C. sinensis 'Maltaise Sanguine) $>$ Mausami (C. sinensis 'Valancia') $>$ Kinnow $($ C. reticulata $)>$ Grapefruit $(C$. paradisi 'Macfadyen') > Fruiter (C. reticulata Blanco 'Merisol').

Moreover, the $\mathrm{IC}_{50}$ values of citrus peel extracts in the present analysis are in line to those investigated by Kalpna et al. $(2011)^{25}$ previously for fruits peels $(16.5-790 \mu \mathrm{g} / \mathrm{g})$ taken from India. However, the presently recorded $\mathrm{IC}_{50}$ values for different citrus peel extracts are relatively lower than those reported by Chen et al. $(2010)^{9}$ for ethanolic extract $(36.595-27.753 \mathrm{mg} / \mathrm{mL})$ of Citrus reticulata Blanco analyzed from Wenzhou and Lishui area of Zhejian province, China supporting that antioxidants activity of citrus peel extracts may not only vary due to extraction solvents but also due to origin of species fruit.

\section{Reducing power}

Many scientific studies reveal that there is a direct relation between antioxidant activity and reducing capacity of plant extracts. Therefore, reducing capacity may be used as an indicator of potential antioxidant activity of a plant material. In this method ferric ions $\left(\mathrm{F}^{+3}\right)$ ions are reduced under specified conditions to ferrous ions $\left(\mathrm{F}^{+2}\right)$ and with this there can be observed a change in solution color from yellow to bluish green. The intensity of the color directly relates to the reducing potential of the compounds present in the extract medium and thus is linked with antioxidant activity ${ }^{42}$. In this regard, $\mathrm{EC}_{50}$ is the concentration of extract which offers 0.50 absorbance measured spectrophotometrically. An inverse relation exists between $\mathrm{EC}_{50}$ and reducing potential. 
The $\mathrm{EC}_{50}$ data for Citrus species peel extracts, produced by different solvents, ranged from 2.01 to $6.76 \mathrm{mg} / \mathrm{mL}$ of extract (Table 3). The lowest $\mathrm{EC}_{50}$ was noted for Red blood (C. sinensis 'Maltaise Sanguine) peel extract (2.01 $\mathrm{mg} / \mathrm{mL}$ ) produced by $80 \%$ methanol as extraction solvent while the highest for Fruiter (C. reticulata Blanco 'Merisol') peel extract $(6.76 \mathrm{mg} / \mathrm{mL})$ with $80 \%$ ethanol indicating a highest and lowest reducing/antioxidant potential of the former and the later, respectively. $\mathrm{EC}_{50}$ values $(\mathrm{mg} / \mathrm{mL})$ for different Citrus species peels were recorded to be 3.34-6.76 for Fruiter (C. reticulata Blanco 'Merisol'), 2.28-3.54 for Grapefruit (C. paradisi 'Macfadyen'), 2.23-4.85 for Kinnow (C. reticulata), 2.09-6.61 for Mausami (C. sinensis 'Valancia') and 2.01-3.98 for Red blood (C. sinensis 'Maltaise Sanguine). Meanwhile, the extraction efficacy of solvents to extract potent reducing agents from citrus peels was found to be in the order of: $80 \%$ methanol $>80 \%$ ethanol $>$ $100 \%$ methanol $>100 \%$ ethanol. The magnitude of reducing potential within different citrus peels was recorded to be Red blood (C. sinensis 'Maltaise Sanguine) $>$ Grapefruit $(C$. paradisi 'Macfadyen') $>$ Kinnow $(C$. reticulata $)$ $>$ Mausami $(C$. sinensis 'Valancia') $>$ Fruiter $(C$. reticulata Blanco 'Merisol') indicating a significant $(p<0.05)$ variations among species selected. In an earlier study, $\mathrm{EC}_{50}(1.88 \mathrm{mg} / \mathrm{mL})$ investigated for Bitter orange by Karoui and Marzouk (2013) $)^{43}$ from Tunisia was lowered than the present $\mathrm{EC}_{50}$ value. Such variation of reducing potential of peels might be linked to varying nature of citrus species.

Composition of Phenolics by HPLC

Qualitative and quantitative analysis of individual phenolic acids in different peel extract using HPLC showed the presence of ten phenolic acids including Gallic acid, Caffeic acid, Chlorogenic acid, Protocatechuic acid, Hydroxybanzoic acid, Syringic acid, 4-Hydroxyl benzoic acid, $p$-Coumaric acid, 3,5-Dihydroxybnezoic acid and Vanillic acid (Table 4). Total amount of phenolic acids within the peels of different citrus species ranged from 18.37 to $1015.99 \mathrm{mg} / \mathrm{kg}$ of extract. Overall, the lowest value of total phenolic acids was found in Grapefruit (C. paradisi 'Macfadyen') peel extract with $100 \%$ methanol $(18.37 \mathrm{mg} / \mathrm{kg}$ ) while the highest for Red blood (C. sinensis 'Maltaise Sanguine) peel extract with $80 \%$ methanol $(1015.99 \mathrm{mg} / \mathrm{kg})$. Total amount of phenolic acids for different species $(\mathrm{mg} / \mathrm{kg}$ ) ranged from 1015.99-336 for Red blood (C. sinensis 'Maltaise Sanguine), 649.96-105.13 for Mausami $C$. sinensis 'Valancia'), 376.65-18.37 for Grapefruit (C. paradisi 'Macfadyen'), 564.6-163.69 for Kinnow (C. reticulata) and 787.93-159.91 for Fruiter $(C$. reticulata Blanco 'Merisol') revealing significant $(p<0.05)$ variations among species.

The presently studied phenolic acids profile of citrus peel extracts was also affected in relation to extraction solvents. The most efficient solvent which extracted the highest amount of phenolic acids was $80 \%$ ethanol while 100 $\%$ methanol was the least effective. Gallic acid was found to be present in the extracts of all citrus peel samples except $100 \%$ methanol extract of Fruiter $(C$. reticulata Blanco 'Merisol'), 80 \% methanol extract of Kinnow (C. reticulata) and $100 \%$ ethanol extract of Kinnow (C. reticulata). The amount of gallic acid within the peel extracts varied over a broad range, $11.96-96.08 \mathrm{mg} / \mathrm{kg}$. The highest amount of gallic acid was extracted from Red blood (C. sinensis 'Maltaise Sanguine) with $100 \%$ methanol while the lowest from Mausami (C. sinensis 'Valancia') with $80 \%$ methanol. Caffeic acid (CA) was present only in 100 and $80 \%$ methanolic extracts of peels with its contribution within the range of 32.74-757.24 mg/kg. The highest amount of CA was detected in $80 \%$ methanolic extract of Red blood (C. sinensis 'Maltaise Sanguine) whereas the least in $80 \%$ methanolic extract of Fruiter (C. reticulata Blanco 'Merisol'). The range for protcatechuic acid varied over $109.18-578.59 \mathrm{mg} /$ $\mathrm{kg}$. Other important phenolics such as 4-hydroxyl benzoic acid $(179.2 \mathrm{mg} / \mathrm{kg})$ and 3,5-dihydroxyl benzoic acid $(182.85 \mathrm{mg} / \mathrm{kg})$ were only present in $100 \%$ ethanol extract of Fruiter (C. reticulata Blanco 'Merisol') and $80 \%$ ethanol extract of Red blood (C. sinensis 'Maltaise Sanguine').

The amount of individual phenolic acids in peel extracts was significantly varied in relation to different extraction solvents as well as Citrus species. Such variations might be due to the fact that different solvents depending upon their polarity and the chemical nature of extractable components extracted different amounts of phenolic acids from the peels so different phenolics might be individually extracted by using specific solvent extraction. The values for different phenolic acids detected in the present analysis of citrus peel extracts were quite lower than those reported by Xu et al. $(2008)^{44}$ for peels of different Citrus species from China. Interestingly, the presently investigated contents of phenolic acids in citrus peel extracts are greater than that studied in different berries except cranberries ${ }^{45}$ supporting that Citrus peels are a rich source of phenolic acids.

\section{CONCLUSION}

The extraction yield from tested peels was varied over a wide range and was affected both by the extraction solvent as well Citrus species. Relatively a higher extraction yield and TPC were obtained by $100 \%$ methanol whereas maximum TFC and DPPH free radical scavenging potential was noted for 100 $\%$ ethanol extracts. The reducing power and amounts of phenolic acids were found to be greater for $80 \%$ methanol extracts of peels. Such variations of antioxidant attributes of citrus peels can be linked to varying chemicals nature of the extractable compounds as well as polarity of the solvents used. It can be said that assessment of antioxidants attributes of citrus peels needs selection of appropriate extraction solvent and multiple assays analysis. As such both the nature of extraction solvent and citrus species has notable effect on the antioxidant and phenolics of citrus peels. Overall, the results showed that citrus peel extracts are a potential source of natural antioxidants; however, peel of Red blood (C. sinensis 'Maltaise Sanguine') has superior antioxidant activity and greater amount of phenolic acids.

Table 2: Total phenolic and flavonoid contents of extracts from different Citrus species.

\begin{tabular}{|c|c|c|c|c|c|c|c|c|}
\hline & \multicolumn{4}{|c|}{ TPC (mg GAE/g) } & \multicolumn{4}{|c|}{ TFC (mg CE/g) } \\
\hline Samples & $\begin{array}{c}100 \% \\
\text { methanol }\end{array}$ & $\begin{array}{c}80 \% \\
\text { methanol }\end{array}$ & $\begin{array}{l}100 \% \\
\text { ethanol }\end{array}$ & $\begin{array}{l}80 \% \\
\text { ethanol }\end{array}$ & $\begin{array}{c}100 \% \\
\text { methanol }\end{array}$ & $\begin{array}{c}80 \% \\
\text { methanol }\end{array}$ & $\begin{array}{l}100 \% \\
\text { ethanol }\end{array}$ & $\begin{array}{l}80 \% \\
\text { ethanol }\end{array}$ \\
\hline $\begin{array}{l}\text { Mausami } \\
\text { (C. sinensis } \\
\text { 'Valancia') }\end{array}$ & $60.52 \pm 0.11_{\mathrm{A}}^{\mathrm{a}}$ & $30.18 \pm 0.12^{\mathrm{b}}{ }_{\mathrm{A}}$ & $23.40 \pm 0.13^{\mathrm{c}}{ }_{\mathrm{A}}$ & $21.11 \pm 0.21_{\mathrm{A}}^{\mathrm{d}}$ & $25.61 \pm 0.06^{\mathrm{a}}{ }_{\mathrm{A}}$ & $11.16 \pm 0.27^{\mathrm{b}}{ }_{\mathrm{A}}$ & $9.34 \pm 0.02^{\mathrm{c}}{ }_{\mathrm{A}}$ & $10.41 \pm 0.02^{\mathrm{d}}{ }_{\mathrm{A}}$ \\
\hline $\begin{array}{c}\text { Red blood } \\
\text { (C. sinensis 'Maltaise } \\
\text { Sanguine) }\end{array}$ & $62.38 \pm 0.25^{\mathrm{a}}{ }_{\mathrm{C}}$ & $20.86 \pm 0.07_{C}^{b}$ & $13.69 \pm 0.13^{c}{ }_{C}$ & $26.73 \pm 0.07^{\mathrm{d}}{ }_{\mathrm{C}}$ & $28.91 \pm 0.03^{\mathrm{a}}{ }_{C}$ & $17.65 \pm 0.08^{\mathrm{b}}{ }_{\mathrm{C}}$ & $21.65 \pm 0.01^{\mathrm{c}}{ }_{\mathrm{C}}$ & $19.33 \pm 0.07^{\mathrm{d}}{ }_{\mathrm{C}}$ \\
\hline $\begin{array}{c}\text { Kinnow } \\
\text { (C. reticulata) }\end{array}$ & $66.10 \pm 0.17^{\mathrm{a}}{ }_{\mathrm{D}}$ & $37.05 \pm 0.24^{\mathrm{b}}$ & $35.92 \pm 0.13^{\mathrm{c}}{ }_{\mathrm{D}}$ & $28.20 \pm 0.19^{\mathrm{d}}{ }_{\mathrm{D}}$ & $25.54 \pm 0.14^{\mathrm{a}}{ }_{\mathrm{D}}$ & $17.33 \pm 0.03^{b}{ }_{D}$ & $29.43 \pm 0.05^{\mathrm{c}}{ }_{\mathrm{D}}$ & $14.28 \pm 0.07^{\mathrm{d}}$ \\
\hline
\end{tabular}

Values are means $\pm \mathrm{SD}(\mathrm{n}=3)$ of three separate experiments. Different caps letter in subscript within the same column show significant $(p<0.05)$ differences of means among Citrus species. Different superscript letters within the same row show significant $(p<0.05)$ differences of means among extraction solvent. 
Table 3: DPPH Radical scavenging activity and reducing power of extracts from different Citrus species.

\begin{tabular}{|c|c|c|c|c|c|c|c|c|}
\hline & \multicolumn{4}{|c|}{ DPPH Radical scavenging activity (mg/mL) } & \multicolumn{4}{|c|}{ Reducing power $(\mathrm{mg} / \mathrm{mL})$} \\
\hline Samples & $\begin{array}{c}100 \% \\
\text { methanol }\end{array}$ & $\begin{array}{c}80 \% \\
\text { methanol }\end{array}$ & $\begin{array}{l}100 \% \\
\text { ethanol }\end{array}$ & $\begin{array}{l}80 \% \\
\text { ethanol }\end{array}$ & $\begin{array}{c}100 \% \\
\text { methanol }\end{array}$ & $\begin{array}{c}80 \% \\
\text { methanol }\end{array}$ & $\begin{array}{l}100 \% \\
\text { ethanol }\end{array}$ & $80 \%$ ethanol \\
\hline $\begin{array}{l}\text { Red blood (C. sinensis } \\
\text { 'Maltaise Sanguine) }\end{array}$ & $0.67 \pm 0.00^{\mathrm{a}}{ }_{\mathrm{A}}$ & $0.45 \pm 0.01^{\mathrm{b}}{ }_{\mathrm{A}}$ & $0.37 \pm 0.00^{\mathrm{c}}{ }_{\mathrm{A}}$ & $0.66 \pm 0.06^{\mathrm{a}}{ }_{\mathrm{A}}$ & $3.98 \pm 0.05^{\mathrm{a}}{ }_{\mathrm{A}}$ & $2.05 \pm 0.14^{\mathrm{b}}{ }_{\mathrm{A}}$ & $2.36 \pm 0.04_{\mathrm{A}}^{\mathrm{c}}$ & $2.42 \pm 0.14^{\mathrm{d}}{ }_{\mathrm{A}}$ \\
\hline $\begin{array}{l}\text { Mausami (C. sinensis } \\
\text { 'Valancia') }\end{array}$ & $0.67 \pm 0.00^{\mathrm{a}}{ }_{\mathrm{B}}$ & $0.45 \pm 0.01^{\mathrm{b}}$ & $0.76 \pm 0.02^{\mathrm{c}}{ }_{\mathrm{B}}$ & $0.75 \pm 0.02^{\mathrm{a}}{ }_{\mathrm{B}}$ & $3.77 \pm 0.06^{\mathrm{a}}$ & $2.09 \pm 0.06^{\mathrm{b}}{ }_{\text {B }}$ & $6.61 \pm 0.12^{\mathrm{c}}{ }_{\mathrm{B}}$ & $3.53 \pm 0.10^{\mathrm{d}}{ }_{\mathrm{B}}$ \\
\hline Kinnow (C. reticulata) & $1.18 \pm 0.06^{\mathrm{a}}{ }_{\mathrm{B}}$ & $0.33 \pm 0.01^{\mathrm{b}}$ & $0.93 \pm 0.03^{\mathrm{c}}{ }_{\mathrm{B}}$ & $0.39 \pm 0.00^{\mathrm{a}}$ & $4.85 \pm 0.15^{\mathrm{a}}{ }_{\mathrm{C}}$ & $2.23 \pm 0.47^{\mathrm{b}}{ }_{\mathrm{C}}$ & $4.32 \pm 0.36^{c}{ }_{C}$ & $2.99 \pm 0.24_{\mathrm{C}}^{\mathrm{d}}$ \\
\hline $\begin{array}{c}\text { Fruiter (C. reticulata } \\
\text { Blanco 'Merisol') }\end{array}$ & $0.66 \pm 0.00^{\mathrm{a}}{ }_{\mathrm{C}}$ & $2.32 \pm 0.02^{\mathrm{b}}{ }_{\mathrm{C}}$ & $1.23 \pm 0.00^{\mathrm{c}}{ }_{\mathrm{C}}$ & $1.26 \pm 0.67^{\mathrm{a}}{ }_{\mathrm{C}}$ & $3.34 \pm 0.07^{\mathrm{a}}{ }_{\mathrm{D}}$ & $3.54 \pm 0.02^{\mathrm{b}}{ }_{\mathrm{D}}$ & $3.84 \pm 0.03^{\mathrm{c}}{ }_{\mathrm{D}}$ & $6.76 \pm 0.28^{\mathrm{d}}{ }_{\mathrm{D}}$ \\
\hline $\begin{array}{c}\text { Grapefruit (C. paradisi } \\
\text { 'Macfadyen') }\end{array}$ & $0.62 \pm 0.01_{\mathrm{B}}^{\mathrm{a}}$ & $0.50 \pm 0.09^{\mathrm{b}}{ }_{\mathrm{B}}$ & $1.2 \pm 0.04^{\mathrm{c}}{ }_{\mathrm{B}}$ & $0.74 \pm 0.30^{\mathrm{a}}{ }_{\mathrm{B}}$ & $3.53 \pm 0.21^{\mathrm{a}}$ & $2.76 \pm 0.09_{\mathrm{E}}^{\mathrm{b}}$ & $3.21 \pm 0.09_{\mathrm{E}}^{\mathrm{c}}$ & $2.28 \pm 0.03^{\mathrm{d}}$ \\
\hline
\end{tabular}

Values are means $\pm \mathrm{SD}(\mathrm{n}=3)$ of three separate experiments. Different caps letter in subscript within the same column show significant $(p<0.05)$ differences of means among Citrus species. Different superscript letters within the same row show significant $(p<0.05)$ differences of means among extraction solvents.

Table 4: Individual phenolic acids ( $\mathrm{mg} / \mathrm{kg}$ of extract) profile of extracts from different Citrus fruits peels.

\begin{tabular}{|c|c|c|c|c|c|c|c|c|c|c|c|c|}
\hline \multirow[t]{2}{*}{ Extract } & $\begin{array}{c}\text { Citrus Peel } \\
\text { Sample }\end{array}$ & \multicolumn{10}{|c|}{ Phenolic Acids (mg/kg of extract) } & \multirow{2}{*}{$\begin{array}{c}\text { Total } \\
\text { amount of } \\
\text { phenolic } \\
\text { acids (mg/ } \\
\text { Kg) }\end{array}$} \\
\hline & & $\begin{array}{c}\text { Gallicl } \\
\text { acid }\end{array}$ & $\begin{array}{l}\text { Caffic } \\
\text { acid }\end{array}$ & $\begin{array}{l}\text { Chloro } \\
\text { genic } \\
\text { acid }\end{array}$ & $\begin{array}{l}\text { Proto } \\
\text { catechuic } \\
\text { acid }\end{array}$ & $\begin{array}{c}\text { 3-Hydroxy } \\
\text { benzoic } \\
\text { acid }\end{array}$ & $\begin{array}{l}\text { Syringic } \\
\text { acid }\end{array}$ & $\begin{array}{l}\text { 4-Hydroxy } \\
\text { benzoic } \\
\text { acid }\end{array}$ & $\begin{array}{c}p- \\
\text { Coumaric } \\
\text { acid }\end{array}$ & $\begin{array}{c}3,5 \\
\text { Dihy- } \\
\text { droxy- } \\
\text { lbenzoic } \\
\text { acid }\end{array}$ & $\begin{array}{c}\text { Vanillic } \\
\text { acid }\end{array}$ & \\
\hline \multirow{5}{*}{$\begin{array}{c}100 \% \\
\text { methanol }\end{array}$} & Red blood & 96.08 & 89.26 & - & 151.35 & - & - & - & - & - & - & 336.69 \\
\hline & Mausami & 20.65 & 89.71 & 11.92 & _- & - & - & - & - & - & - & 122.28 \\
\hline & Grapefruit & 18.37 & _- & _ & _- & _- & _- & _- & _- & _- & _- & 18.37 \\
\hline & Fruiter & _- & _- & _- & 564.6 & _- & _- & _- & _- & _- & _- & 564.6 \\
\hline & Kinnow & 45.61 & _- & _- & 111.74 & 126.4 & _- & _- & _- & _- & _- & 283.75 \\
\hline \multirow{5}{*}{$\begin{array}{c}80 \% \\
\text { methanol }\end{array}$} & Red blood & 14.05 & 757.24 & _ & 244.70 & $\ldots$ & - & _- & _- & _- & _- & 1015.99 \\
\hline & Mausami & 66.48 & 38.65 & _- & & & _- & & _- & _- & $\ldots$ & 105.13 \\
\hline & Grapefruit & 26.72 & & - & 223.15 & & 126.78 & - & - & - & - & 376.65 \\
\hline & Fruiter & 81.63 & 32.74 & _- & & 107.62 & _- & _- & _- & - & _- & 221.99 \\
\hline & Kinnow & & _- & _- & 159.91 & & - & - & - & _- & _ & 159.91 \\
\hline \multirow{5}{*}{$\begin{array}{l}100 \% \\
\text { ethanol }\end{array}$} & Red blood & 64.38 & $\ldots$ & _- & 578.59 & 75.80 & - & - & - & _ & - & 718.77 \\
\hline & Mausami & 82.76 & _- & 107.29 & _- & 459.91 & _- & _- & _- & _- & _- & 649.96 \\
\hline & Grapefruit & 27.41 & - & - & - & _- & - & - & - & - & - & 27.41 \\
\hline & Fruiter & 25.12 & _- & _ & _ & _ & _ & 179.2 & - & - & - & 204.32 \\
\hline & Kinnow & & _- & - & 399.5 & - & - & - & 42.30 & _- & _ & 441.8 \\
\hline \multirow{5}{*}{$\begin{array}{c}80 \% \\
\text { ethanol }\end{array}$} & Red blood & 77.99 & _- & _ & _ & _- & _- & _- & _- & 182.85 & 264.98 & 525.82 \\
\hline & Mausami & 11.96 & _ & 108.17 & _ & _- & 132.88 & _ & _- & _- & _- & 253.01 \\
\hline & Grapefruit & 25.02 & - & - & - & - & - & - & - & - & - & 25.02 \\
\hline & Fruiter & 12.60 & _- & _- & 109.18 & _- & _- & _- & 41.91 & _- & _- & 163.69 \\
\hline & Kinnow & 91.62 & _ & - & 481.80 & - & 162.93 & - & 51.58 & - & _ & 787.93 \\
\hline
\end{tabular}




\section{REFERENCES}

1.- F. Anwar, A.S. Chatha, A.I. Hussain, Grasas Y Aceites, 58(4), 390-395 (2007).

2.- Shinde, J. Ganu, P. Naik, Journal of Dental \& Allied Sciences, 1(2), 63-66 (2012)

3.- N. Akram, F. Anwar, S.A. Raza, Asian Journal of Chemistry, 21(4), 27892798 (2009)

4.- F. Anwar, A.I. Hussain, S. Iqbal, M.I. Bhnanger, Food Chemistry, 103, 1181-1191. (2007).

5.- B. Sultana, F. Anwar, M.R. Asi, S.A.D. Chatha, Grasas Y Aceites, 59(3), 205-217 (2008).

6.- J.J. Yeh, L.H. Hsieh, K.M. Wu, F.C. Tsai, Molecules, 16, 3197-3211 (2011).

7.- F. Anwar, R. Naseer, M.I. Bhanger, S. Ashraf, F.N. Talpor, F.A. Aladedunye, Journal of the American Oil Chemists' Society, 85, 321-330 (2008).

8.- S. Sen, R. Chakraborty, C. Sridhar, S.R. Reddy, B. De, International Journal of Pharmaceutical Science Review and Research, 3(1), 91-100. 2010 .

9.- Y. Chen, K. Yuan, H. Liu, Journal of Food and Environment, 8, 150-155. 2010.

10.- J. Gull, B. Sultana, F. Anwar, R. Naseer, M. Ashraf, M. Ashrafuzzaman, Molecules, 17, 3165-3180 (2012).

11.- N.S. Rajkumar, S.M. Hande, Indian Journal of Pharmaceutical Sciences, 73(2), 146-151 (2011).

12.- D.E. Okwu, International Journal of Sciences, 6(2), 451-471 (2008).

13.- L. Ram, S. Singh, Agriculture Review, 27(3), 170-180 (2006).

14.- M. Shukla, U. Singh, P. Singh, R.L. Singh, Journal Ecophysiology and Occupational Health, 9, 97-103 (2007).

15.- K.A. Kumar, M. Narayani, A. Subanthini, M. Jayakumar, International Journal of Engineering Science and Technology, 3(9), 5414-5421 (2011).

16.- M. Karsheva, E. Kirove, S. Alexandrova, Journal of Chemical Technology and Metallurgy, 48(1), 35-41 (2013).

17.- Foreign Agricultural service/USDA., Department of Agriculture, United States, 1-2. (2013).

18.- K. Ghasemi, Y. Ghasemi, M.A. Ebrahimzadeh, Pakistan Journal of Pharmaceutical Sciences, 22(3) 277-281 (2009).

19.- K.S. Zulkifi, N. Abdullah, A. Abdullah, N. Aziman, W.S.S.W. Kamarudin, International Proceedings of Chemical, Biological and Environmental Engineering, 49, 66-70 (2012).

20.- E. Sikora, E. Cieslik, K. Topolska, ACTA Scientiarum Polonorum Technologia Alimentaria, 7(1), 5-17 (2008).

21.- M.C. Tan, C.P. Tan, C.W. Ho, International Food Research Journal, 20(6), 3117-3123 (2013).

22.- M. Delfanian, R.E. Kenari, M.A. Sahari, Food Sci Nutr., 3(3), 179-187 (2015).

23.- S. Iqbal, Maqbool, H. Sial, Z. Hussain, International Journal of Agriculture and Applied Sciences, 1(2), 68-75 (2009).

24.- B. Sultana, F. Anwar, R. Przybylski, Food Chemistry, 104, 997-1005 (2007)

25.- R. Kalpna, K. Mital, C. Sumitra, Journal of Medicinal plants Research, 5(1), 63-71 (2011)

26.- J. Zhishen, T. Mengchemg, W. Jianming, Food Chemistry, 64, 555-559 (1999).

27.- Y. Zhuang, L. Chen, L. Sun, J. Cao, Journal of Functional Foods, 4, 331338 (2012).

28.- Z. I. Sajid, F. Anwar, G. Rasul, K.M. Alkharfy, A.H. Gilani, Molecules, 17, 3917-3932 (2012).

29.- R.A. Baily, Cambridge university press, (2008).

30.- J. S. Kim, Food and Nutrition Sciences, 4, 177-188 (2013).

31.- P. H. Shie, H.L. Lay, Academia Journal of Medicinal Plants, 1(3), 49-58 (2013).

32.- B. Hasu, I. M. Coupar, K. K. Ng, Food Chemistry, 98, 317-328 (2006).

33.- F. Karadeniz, H.S. Burdurlu, N. Koca, Y. Soyer, Turkish Journal of Agriculture and Forestry, 29, 297-303 (2005).

34.- S. Tunchaiyaphum, M. N. Eshtiaghi, N. Yoswathana, International Journal of Chemical Engineering and Applications, 4(4), (2013).

35.- E. Hegazy, M.I. Ibrahium, World and Applied sciences Journal, 18(5), 684-688 (2012).

36.- B. Li, B. Smith, H. Hossain, Separation and purification technologies, 48(2), 182-188 (2006).
37.- A. Mathur, S.K. Verma, R. Purohit, V. Gupta, V.K. Dua, G.B.K.S. Prasad, IJPI's Journal of Biotechnology and Biotherapeutics, 1(2), 1-17 (2011).

38.- G. Zvaigzne, D. Karklina, D. Seglina, I. Krasnova, Chemine Technologija, 3(52), 56-61 (2009).

39.- M. Manzoor, F. Anwar, N. Saari, M. Ashraf, Molecules, 17, 390-407 (2012).

40.- M. S. Mokbel, F. Hashinaga, Food Chemistry, 94, 529-534 (2006).

41.- A. Sanchez-Moreno, J.A. Larruauri, F. Saura-Calixto, Food Research International, 32, 407-412 (1999).

42.- F. Anwar, H.M. Abdul Qayyum, A.I. Hussain, S. Iqbal, Grasas Y Aceites, 61(3), 237-243 (2010)

43.- J.I. Karoui, B. Marzouk, Bio Med Research International, 1-12 (2013)

44.- G.H. Xu, J.C. Chen, D.H. Liu, P. Zhang, X.Q. Ye, Journal of Food Science, 73(1), C11-C18 (2008).

45.- S. Häkkinen, Kuopio University Publications D., 221, (2000). 